\title{
Status of Groundnut Early Leaf Spot (Cercospora arachidicola) at Hot Semi-arid Ecoregion of Gujarat (India): Past, Present and Future
}

\author{
Thirumalaisamy PP ${ }^{1}$, M Narayana Bhat ${ }^{2}$, Shabistana Nisar ${ }^{2}$, Satish \\ Kumar Yadav' ${ }^{2}$ Puran Chandra ${ }^{2}$ and Sengottaiyan Vennila ${ }^{2 *}$ \\ ${ }^{1}$ ICAR-National Bureau of Plant Genetic Resources, Regional Station, Thrissur, \\ Kerala, India \\ ${ }^{2}$ ICAR-National Research Centre for Integrated Pest Management, L.B.S. Building, \\ Pusa, New Delhi, India
}

*Corresponding Author: Sengottaiyan Vennila, ICAR-National Research Centre for Integrated Pest Management, L.B.S. Building, Pusa, New Delhi, India.
Received: June 25, 2021

Published: July 29, 2021

(C) All rights are reserved by Sengottaiyan

Vennila.

\begin{abstract}
Status of early leaf spot (Cercospora arachidicola) of groundnut over six kharif seasons (2011 - 2016) at hot semi-arid region of Junagadh (Gujarat) was analysed in relation to climatic change and validated using 2020 datasets in addition to its prediction for the future periods of 2050 and 2080. Variability existed for the initiation and mean seasonal status of early leaf spot across seasons. While the earliest occurrence was four weeks after sowing (WAS) during 2012, disease severity was found to increase with increase in crop age despite variations in rate of disease progressions. Terminal disease severity in respect of 2014 and 2011 was 61.5 and $53.3 \%$ and less than $40 \%$ during other study seasons. Mean severity was the highest (43.7\%) and lowest (20\%) in 2011 and 2015 , respectively with $27.3 \%$ during 2020. Climatic deviations worked out in comparison with long term average (40 years; 1970 - 2010 ) for the period of 2011-16 had shown a significant increase of maximum temperature and rainfall by $0.63^{\circ} \mathrm{C}$ and $12.4 \mathrm{~mm} / \mathrm{week}$, respectively. Impact of climatic deviations and their relations to severity worked out using Kendall correlations revealed significant influence of increased rainfall increasing severity of early leaf spot during the past and future periods implying that the changing climatic conditions would be conducive for higher early spot disease severity on groundnut.
\end{abstract}

Keywords: Climate Change; Cercospora arachidicola; Early Leaf Spot; Groundnut; Gujarat

\section{Introduction}

Groundnut (Arachis hypogea) is an oilseed crop of importance used both as cooking oil and in confectionery. India cultivates groundnut in 4.81 Mha with production of $6.69 \mathrm{MT}$ with share of 1.59 Mha contributing $32.7 \%$ of the country's groundnut production by Gujarat [1]. Productivity in India is less (16.6 q/ha) compared to China (37.0 q/ha), USA (45.6 q/ha) and Argentina
(30.8 q/ha). Biotic and abiotic stresses combined with poor crop management practices and weak seed supply chain are the major production constraints. Among biotic stresses, leaf spots early (Cercospora arachidicola) and late (Phaeoisariopsis personata) together cause severe defoliation leading to more than $50 \%$ yield reduction $[2,3]$. Brown lesions surrounded by a chlorotic halo on the upper side of leaves is the characteristic symptom of early leaf spot. Since 
groundnut cultivation is mainly during rainy season (kharif), the early leaf spot (ELS), a foliar disease spreads rapidly depending on the intensity and distribution of rainfall. Crop health, productivity and quality are also impaired due to fluctuating climatic conditions in semi-arid regions [4] including Gujarat. Above optimal air and soil temperatures projected for 2070 to 2100 for certain regions of Gujarat leading to reduction in crop growth and development was reported [5]. Present study made an attempt to understand the disease dynamics of ELS and assess the impact of changing climate on its severity at the semi-arid region of Junagarh (Gujarat (GJ)) during the period of 2011-16, 2020 and future periods (2050 and 2080) of the current century.

\section{Materials and Methods}

Groundnut fields of farmers within 25 - $30 \mathrm{~km}$ radius of the Directorate of Groundnut Research, Junagadh (G)) were selected during kharif of 2011 to 2016 and 2020. Sowing of groundnut was taken up between second fortnights of May and July with a spacing of $60 \times 10 \mathrm{~cm}$ or $45 \mathrm{~cm} \mathrm{X} 10 \mathrm{~cm}$ in the region and cultivars such as GG 20, TG 37, G 41 and TPG 45 were grown. A total of 20 fields were selected from 10 villages with each of selected field having a minimum area of one-acre for observations on ELS. Five spots per field were sampled with visual observations of the disease grade on five plants per spot at weekly intervals following the severity rating assessment of one to nine scale [6] and per cent severity was calculated [7]. Mean severity across five spots of each field for a given standard meteorological week (SMW) was calculated. Progression of ELS severity (\%) along crop age (CA) in weeks accounting the sowing time in respect of fields was also calculated and represented graphically. Inter seasonal variability in ELS severity was analyzed for 2011-16 using one-way analysis of variance (ANOVA) and means were compared using Duncan's multiple range test (DMRT).

Standard meteorological week based data of weather viz., maximum and minimum temperature (MaxT and MinT in ${ }^{\circ} \mathrm{C}$ ), and rainfall ( $R F$ in $\mathrm{mm}$ /week) were obtained from meteorological observatory of ICAR-DOGR for periods relating to kharif of 2011-16 (past) and 2020 (current) periods. Climatic 'normals' (40 years' average:1970-2010) of MaxT, MinT and total RF on SMW basis pertaining Junagadh (GJ) were obtained from All India Co-ordinated Improvement Project on Argo Meteorology, Hyderabad (Telangana). Climate change in terms of MaxT, MinT and RF was worked out as deviations between actual values and 'normals' of each variable on
SMW basis for all individual study seasons (2011-16 and 2020). Actual values of MaxT, MinT and RF pertaining to disease observation periods (22-45 SMW) were considered to work out climatic deviations from their respective 'normals' and student ' $\mathrm{t}$ ' test with equal variances was used to quantify the magnitude of climatic change. Kendall's correlation coefficients were worked out between deviations of climatic variables and ELS severity for data aggregated along SMW over past study seasons of 2011-16. Impact of climatic variables on ELS was validated using data on the ELS and climatic deviations of actual values of weather variables (MaxT, MinT, and RF) of 2020 (present) period. The anticipated impact of climate for future periods of 2050 and 2080 was worked out using the data sets of ELS of 2020 and its relation to projected climatic deviations under representative concentration pathway (RCP) 4.5. Kendall's correlations worked out between ELS severity and of the climatic deviations of the past (2011-16), present (2020) and future (2050 and 2080) periods were used to understand the disease status. All statistical analyses were performed using SAS $9.4^{\circledR}$.

\section{Results and Discussion}

Weather conditions play a predominant role in determining the severity of plant disease within a given season and the climate over a period affects the perpetuation and adaptation of pathogens causing plant diseases. Early leaf spot (ELS) symptoms appeared during four, five, seven, eight and 12 weeks after sowing (WAS) in respect of 2012, 2014, 2013, 2015-2016 and 2011 indicating differing periods of onset. Season of 2011 typically had a late start but highest over all other seasons between 14 and 19 weeks of crop age. Late season surge of severity was noticed during 2014 between 19 and 21 WAS. Lowest early and late season ELS severities $(<20 \%)$ were associated with 2013 and 2015, respectively. Disease progression was below $30 \%$ till 13 WAS in all seasons (2011-16) with variations thereafter till crop harvest. Increased severity of ELS with crop age was evident across all seasons (Figure 1). Increased susceptibility of plants to disease with increasing crop age has been well established [8,9]. Seasons of 2011 and 2013 had shown two peaks and such a bimodal disease curve had arisen out of emergence of new healthy leaves, as reported by [10]. The second peak of the severity progression in the bi modal curve was higher than the first and could again be attributable to the increased susceptibility associated with older leaves [11]. Status of ELS across seasons indicated significantly higher mean severity (43.7\%) in 2011 and almost lower by half (20\%) in 2015. While the 
severity levels were par between 2014 and 2016, 2012 and 2013 seasons had on par severity levels with 2016 (Figure 2).

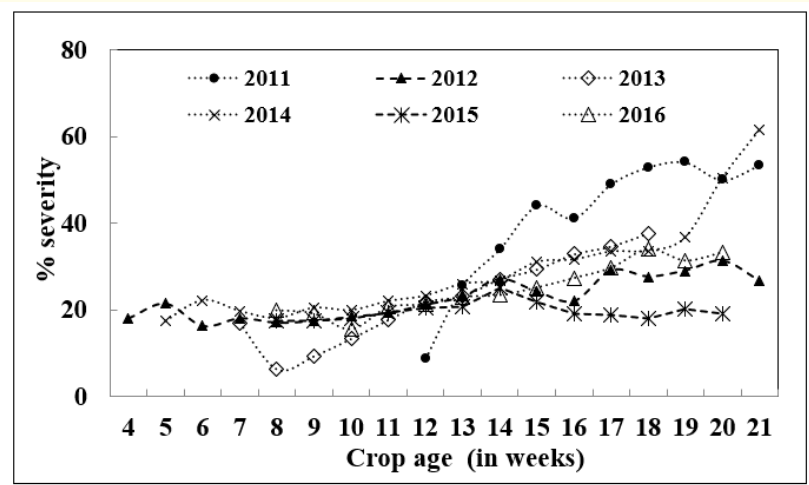

Figure 1: Progression of groundnut early leaf spot at Junagadh (GJ).

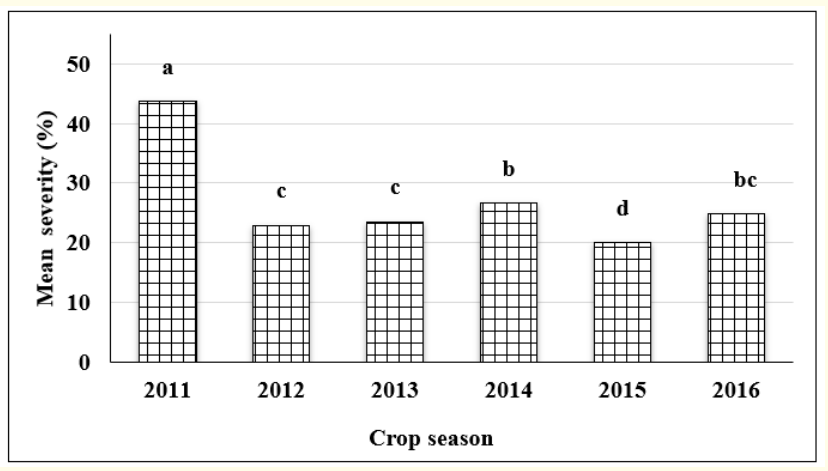

Figure 2: Status of groundnut early leaf spot at Junagadh (GJ) during kharif.

(Bars with the same alphabets are not significantly different at $\mathrm{p}<0.05$ tested using DMRT).

Magnitude of climate change for the kharif (22-45 SMWs) periods aggregated for 2011-16 quantified and tested for their significance over long term 'normals' in respect of temperature (MaxT and MinT ) at Junagadh (GJ) indicated significantly increased maximum temperature $\left(0.63^{\circ} \mathrm{C}\right)$ and rainfall $(12.4 \mathrm{~mm} /$ week). Magnitude of climate change in respect of minimum $\left(-0.45^{\circ} \mathrm{C}\right)$ temperature was non-significant (Table 1). The quantified measures of climate change for the periods of 2011-16 for Banaskantha region situated in the same hot semi-arid region of Gujarat also indicated significantly increasing rainfall ( $33.1 \mathrm{~mm} /$ week) pertaining to pigeonpea crop season (38-51 SMWs) with non-significant changes in temperature [12] confirming the climate change in terms of rainfall amounts at Gujarat.

Kendall correlations worked out between ELS and climatic deviations for the past periods of 2011-16 had shown positive significance of the increasing rainfall with ELS and insignificant relations with temperature (MaxT and MinT) variables (Table 1). It is highly obvious that the increasing rainfall amounts of the past periods directly determined the disease severity of ELS on groundnut at Junagarh (GJ). In field conditions, rainfall is the main source of humidity that makes leaves wet and in turn facilitates higher disease severity. However, during the present period of 2020, the observed rainfall (93 mm/week) (Table 2) was more than double of the past (Table 1) and future periods of 2050 and 2080 (Figure 3). It is interesting to note that the observed seasonal maximum $\left(32.4^{\circ} \mathrm{C}\right)$ and minimum $\left(25.5^{\circ} \mathrm{C}\right)$ temperatures of 2020 was glaringly lower $\left(1.1^{\circ} \mathrm{C}\right)$ and higher $\left(1.4^{\circ} \mathrm{C}\right)$, respectively over the past (2011-2016) periods. Decrease in minimum temperature below $18^{\circ} \mathrm{C}$ together with rise in morning and afternoon relative humidity by 92 and 85 $\%$, respectively contributing significantly to ELS disease severity at Junagarh (GJ) was reported [13]. However, in the current study despite an increased seasonal rainfall during 2020 that could have assisted higher relative humidity, the significance of higher minimum temperature with ELS severity indicated a changed disease scenario under changing climatic variables at Junagadh (GJ).

\begin{tabular}{|l|c|c|c|}
\hline $\begin{array}{l}\text { Climatic } \\
\text { variables }\end{array}$ & $\begin{array}{c}\text { Actual } \\
\text { mean } \\
\mathbf{( 1 1 - 1 6 )}\end{array}$ & $\begin{array}{c}\text { Magnitude } \\
\text { of climate } \\
\text { change }^{\#}\end{array}$ & $\begin{array}{c}\text { Kendall ' } \tau \text { ' coef- } \\
\text { ficients of ELS with } \\
\text { climatic deviations }\end{array}$ \\
\hline Max.T $\left({ }^{\circ} \mathrm{C}\right)$ & 33.5 & $0.63^{*}$ & $0.006^{\mathrm{NS}}$ \\
\cline { 1 - 2 } Min.T $\left({ }^{\circ} \mathrm{C}\right)$ & 24.1 & $-0.45^{\mathrm{NS}}$ & $0.03^{\mathrm{NS}}$ \\
\cline { 1 - 2 }$(\mathrm{mm} /$ & 41.7 & $12.4^{* * *}$ & $0.16^{*}$ \\
\hline week) & & \\
\hline
\end{tabular}

\#: Mean Deviations (Actual minus normal) of variables compared based on Student's ' $t$ ' test and significance of ' $t$ ' and Kendall's ' $\tau$ ' denoted by *: $p<$

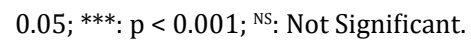

Table 1: Impact of climate change deviations with early leaf spot over seasons (2011-16). 


\begin{tabular}{|l|c|c|c|}
\hline \multirow{2}{*}{$\begin{array}{c}\text { Climatic } \\
\text { variables }\end{array}$} & $\begin{array}{c}\text { Current } \\
\text { period } \\
\mathbf{2 0 2 0}\end{array}$ & \multicolumn{2}{|c|}{ Future periods } \\
\cline { 3 - 4 } Max.T $\left({ }^{\circ} \mathrm{C}\right)$ & $0.05^{\mathrm{NS}}$ & $-0.15^{\mathrm{NS}}$ & $-0.18^{\mathrm{NS}}$ \\
& $(32.4)$ & $(33.8)$ & $(34.2)$ \\
\hline Min.T $\left({ }^{\circ} \mathrm{C}\right)$ & $0.45^{* *}$ & $-0.22^{\mathrm{NS}}$ & $-0.19^{\mathrm{NS}}$ \\
\hline $\begin{array}{l}\text { Rainfall } \\
(\mathrm{mm} /\end{array}$ & $-0.07^{\mathrm{NS}}$ & $0.35^{*}$ & $0.34^{*}$ \\
week) & $(93.0)$ & $(38.4)$ & $(38.7)$ \\
\hline
\end{tabular}

Values outside brackets are Kendall ' $\tau$ ' coefficients between disease severity and deviations of climatic variables and significance of ' $\tau$ ' indicated by $*^{*}$ : $<0.05 ; * *$ : $<0.01$; ${ }^{\text {NS}}$ : not significant. Values inside the brackets are the observed (for 2020) and projected means for future periods (2050 and 2080) in respect of climatic variables.

Table 2: Impact of current and future climate on early leaf spot severity.

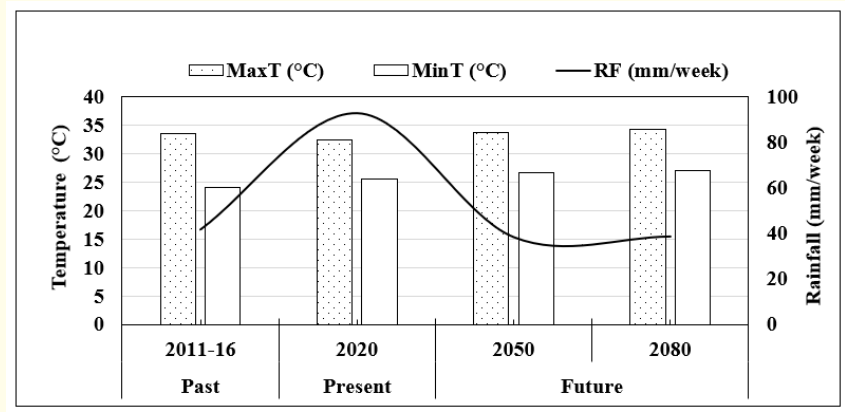

Figure 3: Temperature and rainfall during kharif of groundnut at Junagadh (GJ).

Although many models and their versions projecting climate change scenarios are available, present study used radioactive stabilization scenario of RCP 4.5 as it fitted to the Indian scenario [14] accommodating technologies and strategies that would be implemented in the future years for reducing greenhouse gas emissions. The climatic projections for Junagadh (GJ) made at representative concentration pathway (RCP) 4.5 level (Figure 3) for future peri- ods of current century viz., 2050 and 2080 indicated increasing maximum and minimum temperatures by about 1.8 to $1.6^{\circ} \mathrm{C}$ across locations against the current period of 2020 (Figure 3) confirming increasing temperatures and hence changing climate. The mean ELS severity during 2020 was $27.3 \%$ (progression not shown) and its significant association was noted with the MinT unlike past and future periods where rainfall had a positive significance. The higher minimum temperature vis a vis higher rainfall in 2020 could be attributable to the unseasonal/aberrant nature of weather arising out of western disturbances. The moderate severity of ELS and its significance and non-significance with MinT and RF, respectively during the very high rainfall season of 2020 over the past and future periods indicated the interacting factors of importance influencing status of ELS on groundnut. While positive associations of rainfall and relative humidity in the growth and development of early blight was reported more than a decade earlier [15]. [12] elicited the interplay of increasing temperature and rainfall variables determining disease severity of early blight on tomato at Telangana State that is also being observed with ELS on groundnut at Junagadh (GJ).

\section{Conclusion}

Present study confirmed the changing climate during the kharif of groundnut in terms of temperature and rainfall and the increasing importance of rainfall on ELS during the past and future periods at the Central highland Gujarat plains and Kathiawar peninsula hot semi-arid ecoregion of the agro climatic zone of Gujarat plains and Hills. Under field conditions, ELS could also be influenced by additional factors such as cultivars and planting dates of the production system. With the climate as an environmental variable signifying ELS increase for future, the evolving varietal scenario and changing agronomic practices of groundnut and the adaptation of the pathogen of ELS to those changing situations would determine the disease management strategy to be adopted. An attempt to develop, validate and use weather based models for ELS utilizing the additional weather factors such as relative humidity and rainy days apart from temperature and rainfall could be a way forward to achieve its successful prediction for integration with groundnut pest management during future years of the current decade.

\section{Acknowledgements}

Authors acknowledge the funding by Indian Council of Agricultural Research through 'National Innovations in Climate Resilient 
Agriculture (NICRA)', and staff involved in data collection, entry and uploads from real time pest surveillance centre of Junagadh (Gujarat).

\section{Conflict of Interest}

The authors declare that they have no conflict of interest.

\section{Bibliography}

1. Anonymous. Agricultural statistics at a glance 2019. Government of India. Ministry of Agriculture and Farmers Welfare, Department of Agriculture Cooperation and Farmers Welfare, Directorate of Economics and Statistics. (2019): 315.

2. Jha A., et al. "Effect of biopesticides and fungicides on tikka disease of groundnut (Arachis hypogaea L.)". International Journal of Plant Protection 6.2 (2013): 425-427.

3. Thakur SB., et al. "Variability in groundnut (Arachis hypogaea L.) to Cercospora leaf spot disease tolerance". International Journal of Life Sciences Biotechnology and Pharma Research 2 (2013): 254-262.

4. Varshney RK., et al. "Accelerating genetic gains in legumes for the development of prosperous smallholder agriculture: integrating genomics, phenotyping, systems modelling and agronomy". Journal of Experimental Botany 69.13 (2018): 3293-3312.

5. Patel HR., et al. "Impact of projected climate change on groundnut in Gujarat". Journal of Agro Meteorology 15.1 (2013): 4144.

6. Subrahmanyam P., et al. "Screening methods and sources of resistance to rust and late leaf spot of groundnut". Information Bulletin no. 47. International Crops Research Institute for the Semi-Arid Tropics, Patancheru, Andhra Pradesh, India (1995).

7. Vennila S., et al. "Effect of climatic variability and weather factors on development of tomato early blight in a hot semi-arid region of Southern India". Indian Journal of Horticulture 77.2 (2020a): 333-338.

8. Dey U., et al. "Role of weather factors in development of late leaf spot (Phaeoisariopsis personata) on groundnut (Arachis hypogaea)". Mausam 68.2 (2017): 299-308.
9. Pandey KK and Pandey PK. "Survey and surveillance of vegetable growing area for prevalence of major diseases". Journal of Vegetation Science 30.2 (2003): 128-134.

10. Pandey KK., et al. "Resistance to early blight of tomato with respect to various parameters of disease epidemics". Journal of General Plant Pathology 69.6 (2003): 364-371.

11. Nash AF and Gardner RG. "Tomato early blight resistance in a breeding line derived from Lycopersicon hirsutum PI". Plant Disease 12.3(1988): 206-209.

12. Vennila S., et al. "Status of pod borer Helicoverpa armigera (Hübner) Pigeonpea and its association with climatic variations at a hot semi-arid eco-region of Southern India". Annals of Plant Protection Sciences 28.3 (2020b): 207-212.

13. Samui RP., et al. "Forewarning of incidence of tikka disease on groundnut and operational crop protection using weather information in Gujarat". Mausam 56.2 (2005): 425-432.

14. Ramaraj AP and Geethalakshmi V. "Analysing the uncertainty in climate projected by RCP 4.5 over Coimbatore". Ecology, Environment and Conservation 20 (2014): 125-128.

15. Chaerani R and Voorrips RE. "Tomato early blight (Alternaria solani): the pathogen, genetics and breeding for resistance". Journal of General Plant Pathology 72.6 (2006): 335-347.

\section{Volume 5 Issue 8 August 2021}

(C) All rights are reserved by Sengottaiyan Vennila. 